\title{
A retrospective study of reproductive outcomes after fertility-sparing surgery and postoperative adjuvant chemotherapy in malignant ovarian germ cell tumors and sex cord-stromal tumors
}

\author{
Ning Zhang, Ruifang Chen, Keqin Hua* and Ying Zhang*
}

\begin{abstract}
Background: To retrospectively investigate reproductive outcomes after fertility-sparing surgery and postoperative adjuvant chemotherapy in malignant ovarian germ cell tumors (MOGCT) and sex cord-stromal tumors (SCST).

Methods: Data from 32 MOGCT (6 dysgerminomas, 6 yolk sac tumors, 17 immature teratomas, and 3 mixed germ cell tumors) and 9 SCST (4 granulosa cell tumors and 5 sertoli-leydig cell tumors) aged from 18 to 35, treated in the Obstetrics and Gynecology Hospital of Fudan University from October 2003 to October 2013 were collected and analyzed.

Results: Average follow up was $(86.3 \pm 34.4)$ months. Average diagnosed age was $(25.3 \pm 3.5)$ years. Average chemotherapy course was $(4.4 \pm 1.3)$ times. Patients are all living. Thirty one patients $(75.6 \%)$ reported normal menstrual cycles. Twelve patients (29.3\%) wished to conceive, 10 (83.3\%) naturally conceived and 8 (66.7\%) had lived birth.
\end{abstract}

Conclusions: Reproductive outcomes after fertility-sparing surgery and postoperative adjuvant chemotherapy in MOGCT and SCST are favorable, meanwhile education and consultation is needed.

Keywords: Malignant germ cell tumors, Malignant sex cord-stromal tumors, Fertility-sparing surgery, Postoperative adjuvant chemotherapy, Reproductive outcomes

\section{Background}

Malignant ovarian germ cell tumors (MOGCT) and sex cord-stromal tumors (SCST) are not common. MOGCTs arise from primordial germ cells. Dysgerminoma is the most common histology of MOGCT, followed by immature teratoma and endodermal sinus tumor. SCSTs develop from the gonadal non-germ-cell components [1], including granulosa cell tumors, granulosa-theca tumors, and Sertoli-Leydig cell tumors. MOGCT and SCST are generally occurred in young women, considered low-grade, sensitive to chemotherapy, and good prognosis [2-4]. The 5-year survival rate

\footnotetext{
* Correspondence: huakeqin@gmail.com; 13818218839@163.com Department of Gynecology, The Obstetrics and Gynecology Hospital of

Fudan University, 128 Shenyang RD, Shanghai 200090, China
}

is about 85\% [5] in MOGCT, and 97\% [6] in SCST. Fertility preservation treatment can be achieved in most cases.

According to American National Comprehensive Cancer Network (NCCN) 2017 guideline for ovarian cancer, the standard treatment regimen for MOGCT and stage IA/IC SCST with fertility desiring is fertilitysparing surgery. That is preservation of the uterus and the contralateral ovary with staging procedure. For younger patients with early-stage diseases, comprehensive staging can be omitted. After surgery, adjuvant chemotherapy of bleomycin, etoposide, and cisplatin (BEP) or platinum-based thermotherapy will recommend to certain patients. 
However, pregnancy rate and live birth outcomes after such treatment are not well established of these two diseases. We composed this retrospective study to report and analyze the reproductive outcomes of MOGCT and SCST patients with fertility preservation in our hospital.

\section{Methods}

Thirty two MOGCT and 9 SCST patients conducted fertility-sparing surgery and adjuvant chemotherapy with complete follow up data, younger than 35 years old at first treatment, continuously disease-free with minimum follow-up of 2 years in the Obstetrics and Gynecology Hospital of Fudan University from October 2003 to October 2013 were retrospectively investigated.

Diagnosis of MOGCT or SCST was revealed by pelvic mass, abdominal pain, growing ascites, and arising of tumor markers like $\alpha$-fetoprotein (AFP), human choionic gonadotophin (HCG) and inhibin. The diagnosis was confirmed by surgical procedure and pathological diagnosis. Pathological diagnosis was confirmed according to the 2014 World Health Organization classification of tumors of female reproductive organs by expert gynecological pathologists in our hospital. Tumors were staged according to the International Federation of Gynecology and Obstetrics (FIGO) 2000 staging system for ovarian cancer.

Clinical characteristics including patient age, clinical stage, operation type, chemotherapy regimen, chemotherapy courses, survival length and follow up time were collected and recorded. Reproductive outcomes including pregnancy rate and live birth rate were investigated. Follow-up data until January 31, 2017 was collected from hospital records and telephone interview. This study was approved by the Ethics Committee of the Obstetrics and Gynecology Hospital of Fudan University. Oral informed consents were obtained from all patients.

Patients of MOGCT who desire fertility preservation can be treated with fertility-sparing surgery regardless of stages. SCST patients of stage IA or IC desire fertility preservation can be treated with fertility-sparing treatment. Fertility preservation operation means preserve uterus and the contralateral ovary with or without comprehensive staging (omentectomy and lymphadenectomy) by open laparotomy or laparoscopy. Gynecological oncologists participated in all the operations. For adolescent patients of early-stages, comprehensive staging was omitted.

Chemotherapy was scheduled for embryonal tumors, endodermal sinus tumors, stage II to IV dysgerminoma, stage I, grade 2 to 3 , or stage II to IV immature teratoma. Stage I SCST with high-risk factors, such as tumor rupture, stage IC, tumor size $>10$ $15 \mathrm{~cm}$, poorly differentiated were also recommended chemotherapy. Chemotherapy schemes included BEP, BVP (bleomycin/vincristine/platinum) and VAC (vincristine/actinomycin/cyclophosphamide). In this study, all patients received chemotherapy, but with different schemes and courses.

Statistical analysis was performed using SPSS version 19.0 software (SPSS Inc., Chicago, IL). Continuous variables were described as mean and standard deviation. Student's t test and nonparametric tests were used as appropriate. Chi-squared test and Fisher's exact test were used for group comparisons for categorical variables. The correlation was assessed with Spearman correlation coefficients. Differences were considered to be significant at $p<0.05$.

\section{Results}

There were 45 patients underwent fertility-sparing surgery and postoperative adjuvant chemotherapy in the Obstetrics and Gynecology Hospital of Fudan University from October 2003 to October 2013. Among them 41 patients had completed follow up data. The missed follow-up rate was $8.9 \%$. Clinical characteristics of the 41 patients are revealed in Table 1. Average patients' age was $(25.3 \pm 3.5)$ years old, range from 18 to 31 . Average follow-up duration was $(86.3 \pm 34.4)$ months, range from 39 to 159 months. Among all 41 followed up patients, there were 32 germ cell tumors: 6 dysgerminomas, 6 yolk sac tumors, 3 mixed germ cell tumors and 17 immature teratomas, among those there were 2 cases of grade 3,9 cases of grade 2 and 6 cases of grade 1. Among 9 sex cord-stromal tumors, there were 4 granulosa cell tumors and 5 sertoli-leydig cell tumors. Thirty eight patients were diagnosed in FIGO stage I, 2 in stage II and 1 patient with immature teratoma was stage III. All the tumors in 41 patients were unilateral.

Fertility-sparing surgery with completed surgical staging including pelvic lymphadenectomy and omentectomy was performed in 17 patients. Other patients underwent unilateral salpingo-oophorectomy (USO). No severe complication was recorded in this study. Thirty four patients undertook BEP chemotherapy, 6 with BVP and 1 with VAC. Chemotherapy courses differ from 2 to 7 , with the average of $(4.4 \pm 1.3)$ courses.

Forty one patients are all living. Thirty one patients (75.6\%) reported normal menstrual cycles, while others complained of light volume or shortened duration of menstruation. Menstruation status had no relationship with patients' age $(r s=0.195, P=0.227)$, clinical stage (rs $=0.209, P=0.195)$, operation type ( $r s=-0.263$, $P=0.101)$, nor chemotherapy courses ( $r s=-0.014$, $P=0.932)$.

In all 41 patients, 12 patients $(29.3 \%)$ wished to conceive, others neither not married, nor do not willing to. $8(66.7 \%)$ patients naturally conceived and lived birth 
Table 1 Clinical characteristics of malignant germ cell tumor and sex cord-stromal tumor

\begin{tabular}{|c|c|c|c|}
\hline Characteristic & $\begin{array}{l}\text { Germ cell tumor } \\
(\mathrm{n}=32)\end{array}$ & $\begin{array}{l}\text { Sex cord-stromal tumor } \\
(\mathrm{n}=9)\end{array}$ & $P$ value \\
\hline Follow up (months) & $85.8 \pm 36.0$ & $87.7 \pm 30.2$ & 0.889 \\
\hline Average diagnosed age (years old) & $25.2 \pm 3.5$ & $25.8 \pm 3.8$ & 0.644 \\
\hline \multicolumn{4}{|l|}{ Clinical stage } \\
\hline । & 29 & 9 & / \\
\hline$\|$ & 2 & 0 & / \\
\hline III & 1 & 0 & / \\
\hline \multicolumn{4}{|l|}{ Operation } \\
\hline Laparoscopic/abdominal & $5 / 27$ & $4 / 5$ & 0.087 \\
\hline Complete staging/not staging & $14 / 18$ & $3 / 6$ & 0.711 \\
\hline \multicolumn{4}{|l|}{ Chemotherapy } \\
\hline BEP & 27 & 7 & \\
\hline PVB & 4 & 2 & \\
\hline VAC & 1 & 0 & \\
\hline Chemotherapy Courses & $4.4 \pm 1.3$ & $4.2 \pm 1.2$ & 0.708 \\
\hline GnRHa injection & $14 / 32$ & $1 / 9$ & 0.119 \\
\hline Normal menstruation & $24 / 32$ & $7 / 9$ & 0.864 \\
\hline Pregnancy/willing to conceive & $7 / 9$ & $1 / 3$ & / \\
\hline Live birth/willing to conceive & $6 / 9$ & $1 / 3$ & / \\
\hline Abortion (unexpected pregnancy) & 0 & 2 & / \\
\hline Completion surgery after childbearing & 0 & 0 & / \\
\hline
\end{tabular}

BEP bleomycin/etoposide/platinum, BVP bleomycin/vincristine/platinum, VAC vincristine/actinomycin/cyclophosphamide, GnRHa gonadotropin-releasing hormone agonist

without critical birth defects. There were 2 abortions because of unwilling pregnancy. The pregnant patients all conceived naturally and the pregnancy occurred during 1 to 4 years after treatment, no typical assisted reproductive technology was used (Table 2). In our study, no patient completed staging surgery after childbearing.

\section{Discussion}

The prognosis of MOGCT and SCST is much better than epithelial ovarian cancer. Patients who underwent fertility-sparing surgery were able to maintain ovarian function and fertility after tumor therapy [7]. From our results, $75.6 \%$ of the patients had regular menstruation

Table 2 Characteristics of 8 naturally conceived and lived birth patients

\begin{tabular}{|c|c|c|c|c|c|c|c|c|c|c|}
\hline & $\begin{array}{l}\text { Age of initial } \\
\text { Diagnosis }\end{array}$ & Diagnosis & Stage & $\begin{array}{l}\text { Diagnosis } \\
\text { year }\end{array}$ & Operation & $\begin{array}{l}\text { Operation } \\
\text { type }\end{array}$ & $\begin{array}{l}\text { Chemo } \\
\text { therapy }\end{array}$ & Course & $\begin{array}{l}\text { GnRHa } \\
\text { injection }\end{array}$ & $\begin{array}{l}\text { Interval of pregnancy } \\
\text { and treatment }\end{array}$ \\
\hline$\overline{1}$ & 30 & Dysgerminoma & la & May 2007 & USO & Laparotomy & BEP & 4 & $\mathrm{~N}$ & 2 year \\
\hline 2 & 30 & Yolk sac & lc & May 2009 & $\begin{array}{l}\text { USO Completed } \\
\text { staging }\end{array}$ & Laparotomy & BEP & 6 & $N$ & 2 year \\
\hline 3 & 25 & $\begin{array}{l}\text { Immature } \\
\text { teratoma }\end{array}$ & la & Jun 2010 & USO & Laparotomy & BEP & 2 & $N$ & 4 year \\
\hline 4 & 21 & $\begin{array}{l}\text { Immature } \\
\text { teratoma }\end{array}$ & la & Mar 2004 & USO & Laparotomy & VAC & 4 & $N$ & 2 year \\
\hline 5 & 24 & $\begin{array}{l}\text { Immature } \\
\text { teratoma }\end{array}$ & $\| l \mid b$ & Jul 2006 & $\begin{array}{l}\text { USO Completed } \\
\text { staging }\end{array}$ & Laparotomy & BEP & 6 & $N$ & 3 year \\
\hline 6 & 24 & $\begin{array}{l}\text { Immature } \\
\text { teratoma }\end{array}$ & la & Mar 2004 & USO & Laparotomy & BVP & 4 & $N$ & 1 year \\
\hline 7 & 25 & Dysgerminoma & lc & $\operatorname{Jan} 2013$ & $\begin{array}{l}\text { USO Completed } \\
\text { staging }\end{array}$ & Laparotomy & BEP & 4 & Y & 2 year \\
\hline 8 & 27 & Sertoli-leydig & la & Jan 2008 & USO & Laparotomy & BEP & 3 & N & 3 year \\
\hline
\end{tabular}


after surgery and chemotherapy. In our hospital, laparoscopic surgery was comprehensively developed around 2010. The majority of patients in this study were treated by laparotomy and most of pregnant patients were in laparotomy group. We do not regularly biopsy the normal ovary as it could produce adhesion and scar, which could possibly cause infertility. And second-look surgery is not regularly conducted in our hospital.

Cancer survivors are always worried about the risks of cancer recurrence and the severe adverse impacts on their offspring. Compared to sibling controls, elective abortion rate among female cancer survivors was much higher [8]. In our study, 2 abortions were recorded because of unwilling conceive. Studies revealed that specific effects on pregnancy from chemotherapy without radiotherapy were generally few [9]. Female cancer survivors treated with chemotherapy and/or radiotherapy during childhood do not have higher risks of chromosomal syndromes, single gene disorders, or congenital anomalies in their children [10-14]. In our study, no severe congenital anomaly was reported, but we need long-time follow up.

The optimal time of pregnancy after cancer treatment is not verified. As the time period of follicle development is six months, it is prudent to wait that time period after chemotherapy [15]. And we also recommend a comprehensive assessment of cancer alleviation or cure before attempting conception. In our study, all the pregnancies occurred during 1 to 4 years after treatment. And all pregnant patients conceived naturally without assisted reproductive technology. We suggest fertility preservation before cancer treatment or as early as possible so as to maximize the reproductive potential of all cancer survivors [16]. And for some patients, certain assisted reproductive technology may be helpful.

Education and consultation regarding future reproductive plan is very important for cancer patients and their families [17]. But only half of female cancer survivors received reproductive health counseling [18]. In this study, this data is in lack unfortunately.

From 2010 after, we began to recommend gonadotropinreleasing hormone agonists (GnRHa) for ovarian function protection during chemotherapy without randomization. The efficacy of GnRHa for prevention of ovarian toxicity is still controversial [19]. In this retrospective study, no specific benefit of $\mathrm{GnRHa}$ was revealed.

\section{Conclusions}

Although fertility-sparing surgery and postoperative adjuvant chemotherapy was suitable and safety for MOGCT and SCST, reproductive outcomes are favorable, multiple center study should be conducted to verify our conclusion. Educational consultation about following up and reproductive health should be taken for all the patients and their families.

\section{Abbreviations}

AFP: a-fetoprotein; BEP: Bleomycin, etoposide, and cisplatin; BVP: Bleomycin/ vincristine/platinum; FIGO: International Federation of Gynecology and Obstetrics; GnRHa: Gonadotropin-releasing hormone agonists; HCG: Human choionic gonadotophin; MOGCT: Malignant ovarian germ cell tumors; NCCN: American National Comprehensive Cancer Network; SCST: Sex cordstromal tumors; VAC: Vincristine/actinomycin/cyclophosphamide

\section{Acknowledgements}

This work was supported by the foundation of Shanghai Municipal Commission of Health and Family Planning for young scholars (201344032). Which is helpful for the design of the study and data collection and analysis. The authors thank colleagues in the Medical Record Department in the Obstetrics and Gynecology Hospital of Fudan University for their help. And also thank all the patients who took part in this study.

\section{Availability of data and materials}

Please contact author for data requests.

\section{Authors' contributions}

YZ provided the funding support, designed the study and helped enroll patients. KH helped design the study. RC enrolled patients, NZ collected data and wrote the paper. All authors read and approved the final manuscript.

\section{Ethics approval and consent to participate}

This study was approved by the Ethics Committee of the Obstetrics and Gynecology Hospital of Fudan University. The committee's reference number was 2015(40).

\section{Consent for publication}

Oral informed consents were obtained from all patients for publication related data.

\section{Competing interests}

The authors declare that they have no competing interests.

\section{Publisher's Note}

Springer Nature remains neutral with regard to jurisdictional claims in published maps and institutional affiliations.

Received: 7 April 2017 Accepted: 19 July 2017

Published online: 27 July 2017

\section{References}

1. Quirk JT, Natarajan N. Ovarian cancer incidence in the United States, 1992-1999. Gynecol Oncol. 2005;97:519-23.

2. Murugaesu N, Schmid P, Dancey G, Agarwal R, Holden L, McNeish I, Savage PM, Newlands ES, Rustin GJ, et al. Malignant ovarian germ cell tumors: identification of novel prognostic markers and long-term outcome after multimodality treatment. J Clin Oncol. 2006;24:4862-6.

3. Schumer ST, Cannistra SA. Granulosa cell tumor of the ovary. J Clin Oncol. 2003:21:1180-9.

4. Pectasides D, Pectasides E, Psyrri A. Granulosa cell tumor of the ovary. Cancer Treat Rev. 2008:34:1-12

5. Mangili G, Sigismondi C, Gadducci A, Cormio G, Scollo P, Tateo S, Ferrandina G, Greggi S, Candiani M, et al. Outcome and risk factors for recurrence in malignant ovarian germ cell tumors: a MITO-9 retrospective study. Int J Gynecol Cancer. 2011;21:1414-21.

6. Mangili G, Ottolina J, Gadducci A, Giorda G, Breda E, Savarese A, Candiani M, Frigerio $L$, Scarfone $G$, et al. Long-term follow-up is crucial after treatment for granulosa cell tumours of the ovary. Br J Cancer. 2013;109:29-34.

7. Gershenson DM, Miller AM, Champion VL, Monahan PO, Zhao Q, Cella D, Williams SD, Gynecologic Oncology G. Reproductive and sexual function after platinum-based chemotherapy in long-term ovarian germ cell tumor survivors: a Gynecologic Oncology Group Study. J Clin Oncol. 2007;25:2792-7.

8. Green DM, Whitton JA, Stovall M, Mertens AC, Donaldson SS, Ruymann FB, Pendergrass TW, Robison LL. Pregnancy outcome of female survivors of childhood cancer: a report from the Childhood Cancer Survivor Study. Am J Obstet Gynecol. 2002;187:1070-80. 
9. Barton SE, Najita JS, Ginsburg ES, Leisenring WM, Stovall M, Weathers RE, Sklar CA, Robison LL, Diller L. Infertility, infertility treatment, and achievement of pregnancy in female survivors of childhood cancer: a report from the Childhood Cancer Survivor Study cohort. Lancet Oncol. 2013;14: 873-81.

10. Byrne J, Rasmussen SA, Steinhorn SC, Connelly RR, Myers MH, Lynch CF, Flannery J, Austin DF, Holmes FF, et al. Genetic disease in offspring of longterm survivors of childhood and adolescent cancer. Am J Hum Genet. 1998; 62:45-52.

11. Green DM, Fiorello A, Zevon MA, Hall B, Seigelstein N. Birth defects and childhood cancer in offspring of survivors of childhood cancer. Arch Pediatr Adolesc Med. 1997;151:379-83.

12. Chiarelli AM, Marrett LD, Darlington GA. Pregnancy outcomes in females after treatment for childhood cancer. Epidemiology. 2000;11:161-6.

13. Winther JF, Olsen JH, Wu H, Shyr Y, Mulvihill JJ, Stovall M, Nielsen A, Schmiegelow M, Boice JD Jr. Genetic disease in the children of Danish survivors of childhood and adolescent cancer. J Clin Oncol. 2012;30:27-33.

14. Signorello LB, Mulvihill JJ, Green DM, Munro HM, Stovall M, Weathers RE, Mertens AC, Whitton JA, Robison LL, et al. Congenital anomalies in the children of cancer survivors: a report from the childhood cancer survivor study. J Clin Oncol. 2012;30:239-45.

15. Winkler-Crepaz K, Ayuandari S, Ziehr SC, Hofer S, Wildt L. Fertility preservation in cancer survivors. Minerva Endocrinol. 2015;40:105-18.

16. Chow EJ, Stratton KL, Leisenring WM, Oeffinger KC, Sklar CA, Donaldson SS, Ginsberg JP, Kenney LB, Levine JM, et al. Pregnancy after chemotherapy in male and female survivors of childhood cancer treated between 1970 and 1999: a report from the Childhood Cancer Survivor Study cohort. Lancet Oncol. 2016;17:567-76.

17. Ethics Committee of the American Society for Reproductive M. Fertility preservation and reproduction in cancer patients. Fertil Steril. 2005:83:1622-8.

18. Niemasik EE, Letourneau J, Dohan D, Katz A, Melisko M, Rugo H, Rosen M. Patient perceptions of reproductive health counseling at the time of cancer diagnosis: a qualitative study of female California cancer survivors. J Cancer Survivorship. 2012;6:324-32

19. Demeestere I, Brice P, Peccatori FA, Kentos A, Dupuis J, Zachee P, Casasnovas O, Van Den Neste E, Dechene J, et al. No Evidence for the Benefit of Gonadotropin-Releasing Hormone Agonist in Preserving Ovarian Function and Fertility in Lymphoma Survivors Treated With Chemotherapy: Final Long-Term Report of a Prospective Randomized Trial. J Clin Oncol. 2016;1:34(22):2568-74

\section{Submit your next manuscript to BioMed Central and we will help you at every step:}

- We accept pre-submission inquiries

- Our selector tool helps you to find the most relevant journal

- We provide round the clock customer support

- Convenient online submission

- Thorough peer review

- Inclusion in PubMed and all major indexing services

- Maximum visibility for your research

Submit your manuscript at www.biomedcentral.com/submit

) Biomed Central 